\title{
Don't camp beside the river: structure and dynamics of Andean alder (Alnus acuminata) forests affected by river floods, northwestern Argentina
}

\author{
No acampe junto al río: estructura y dinámica de bosques de aliso (Alnus acuminata) \\ del noroeste argentino afectados por crecientes de río
}

TOMÁS A. EASDALE*, SEBASTIÁN SABATÉ \& ALFREDO GRAU
Laboratorio de Investigaciones Ecológicas de las Yungas, Facultad de Ciencias Naturales, Universidad Nacional de Tucumán, Casilla de Correos 34-CP 4107, Yerba Buena, Tucumán, Argentina;
*e-mail for correspondence: easdalet@yahoo.com.ar

\begin{abstract}
Alnus acuminata (Betulaceae) is a pioneer tree that dominates mountain riparian forests throughout the eastern Andes. Early studies associated these forests with particular microclimatic conditions along river beds, but they were later linked to the periodical disturbance regime of mountain rivers. To understand the dynamics of these forests, we analysed tree age and spatial arrangement in two plots along Potrero river and another plot along La Horqueta river, Tucumán Province, north west Argentina. Through intensive tree coring and age reconstruction we identified similar-aged tree cohorts with maximum age ranges of eight years. Tree mapping and Moran's I spatial autocorrelation analysis showed that tree cohorts were spatially clumped, and provided further evidence that coetaneous patches of $A$. acuminata arise from massive regeneration following catastrophic flooding events. We tested the association between cohort initiation dates and regional maximum river discharge records by means of a randomization procedure and found weak evidence that establishment occurs after devastating floods, which eliminate previous vegetation and create bare sites suitable for $A$. acuminata regeneration. Dates of tree floodscars sampled along Potrero river precede by one year the most recent cohort initiation date and provide further support of this association. Although previous studies found a positive correlation between El Niño events and mean annual precipitation in northwestern Argentina, we did not detect an association between El Niño and annual maximum stream flow for rivers in Tucumán Province. Therefore, factors driving devastating floods and A. acuminata stand initiation require further study.
\end{abstract}

Key words: Alnus acuminata, river floods, riparian forests, forest dynamics, El Niño/ENSO.

\section{RESUMEN}

El aliso (Alnus acuminata, Betulaceae) es un árbol pionero que domina bosques riparios de montaña en los Andes orientales. Estudios iniciales atribuyeron la presencia de estos bosques a las típicas condiciones microclimáticas de cauces de ríos, pero luego estos fueron vinculados al régimen periódico de disturbios de ríos de montaña. Para comprender la dinámica de estos bosques, analizamos la estructura de edades y el arreglo espacial de árboles en dos parcelas sobre el río Potrero y otra parcela sobre el río La Horqueta, en la provincia de Tucumán, noroeste argentino. Mediante barrenado intensivo y reconstrucción de edades identificamos cohortes de árboles con un rango máximo de edades de ocho años. El mapeo de árboles y el índice de autocorrelación espacial I de Moran indicaron que las cohortes de árboles estaban agrupadas en espacio, proporcionando evidencia adicional de que los parches coetáneos de A. acuminata resultan de eventos de regeneración masiva luego de crecientes catastróficas. Evaluamos la asociación entre años de inicio de cohortes y registros regionales de descarga máxima de ríos por medio de aleatorizaciones y encontramos evidencia débil de que los establecimientos ocurren luego de crecientes devastadoras que eliminan la vegetación preexistente y originan sitios desnudos propicios para la regeneración del aliso. Las fechas de cicatrices de crecientes en árboles del río Potrero preceden por un año al inicio de la cohorte más reciente y dan respaldo adicional a esta conexión. A pesar de que estudios previos encontraron una correlación positiva entre eventos de El Niño y promedios de precipitación en el noroeste argentino, nuestros datos no revelan una asociación significativa entre El Niño y caudales máximos anuales en ríos de la provincia de Tucumán. Se requieren más estudios para identificar los factores que originan crecientes devastadoras y cohortes de A. acuminata.

Palabras clave: Alnus acuminata, crecientes de río, bosques riparios, dinámica de bosques, El Niño. 


\section{INTRODUCTION}

Most landscapes are patchy in vegetation structure and species composition (Pickett \& White 1984). Patchiness may originate from spatial or temporal variation in: (1) the availability of establishment sites, (2) propagule dispersal, and/or (3) growth and survival (Sousa 1984). Disturbances create unvegetated sites which are essential for the synchronous recruitment of pioneer species. Therefore, the occurrence of disturbances in forested landscapes typically results in a mosaic of patches of various sizes and ages, many of which comprise cohorts of pioneer trees (Pickett \& White 1984, Sousa 1984, Oliver \& Larson 1996).

This patch dynamics concept applies also to riparian plant communities (Townsend 1989). The flow of rivers varies in time and space, affecting the physical environment, and the recruitment, growth, and survival of riparian vegetation (Friedman et al. 1996, Schweingruber 1996, Ward \& Stanford 1995). The changes in flow dynamics along a river can be noticed in the structure and dynamics of riparian forests. Braided or constrained channels, common at mid or high elevations, are associated with islands or irregular-shaped bands of even-aged trees (Hack \& Goodlet 1960, Scott et al. 1997, Karrenberg et al. 2002) while meandering rivers from the lowlands produce siltation bars that result in arched bands of even-aged trees (Everitt 1968, Bradley \& Smith 1986).

The Andean alder, Alnus acuminata Kunth (Betulaceae), is distinctive for its association with mountain river courses. From Mexico to Ecuador, the species is mainly restricted to terraces of montane rivers, but in southern Bolivia and north west Argentina, it also dominates the mountain slopes between 1,700 and $2,700 \mathrm{~m}$ elevation (the upper montane forest zone) as almost monospecific forests (Hueck 1978, Bell 1991). The riparian forests of $A$. acuminata in north west Argentina are characterized by dense patches of trees with similar heights and diameters, suggesting that they represent even-aged cohorts. The fluvial landscape consists of rocky substrate, large patches of small or medium-sized A. acuminata trees, small patches of large A. acuminata trees, and isolated large trees. Given that $A$. acuminata is a light-demanding pioneer species with efficient recruitment on recently disturbed open soil sites (Grau 1985), these stands may have been originated by mass recruitment after stand-replacing floods. Alnus acuminata riparian forests have previously been attributed to particular microclimatic conditions (Cabrera 1976), but are now thought to result from periodical disturbances (Grau 1985, Aceñolaza 1996).

Climate has a clear influence over the type, magnitude, extension, and frequency of abiotic disturbances in forest landscapes (e.g., Foster 1988, Clark 1988, Overpeck et al. 1990, Swetnam \& Betancourt 1990). This is clearly illustrated by river floods, where size and effect are dependent on weather fluctuations and drainage basin geomorphology (Hack \& Goodlett 1960). In the western hemisphere, El Niño Southern Oscillation (ENSO) is one of the major drivers of climate fluctuations, and these effects are transmitted to the dynamics of many different natural systems (Holmgren et. al. 2001, Jaksic 2001). Recent studies demonstrate increased precipitation over southeastern South America and extreme discharges in the Paraná river associated with El Niño events (Camilloni $\&$ Barros 2003). No previous study has addressed the effect of ENSO on streamflow over NW Argentinean rivers, but the increase in mean annual precipitation over the foothills of the Andes during el Niño years (Trauth et al. 2000) suggests possible effects of El Niño on streamflow and associated plant communities, such as A. acuminata riparian forests.

Previous tree age and flood scar reconstructions in one riparian forest indicate that $A$. acuminata establishes within a four-year period after peak river discharges (Grau et al. 2003). In this study we add tree age reconstructions of two other forest stands and analyze their relationships with river discharge records in Tucumán province (north west Argentina), and an ENSO index, to test whether: (1) A. acuminata riparian forests comprise distinct cohorts, (2) cohorts have originated after major floods, and (3) standreplacing major floods coincide with El Niño events. 


\section{MATERIAL AND METHODS}

\section{Study species}

Alnus acuminata is a light-demanding species with rapid growth, tolerance of nutrient scarcity (it is associated with $\mathrm{N}$-fixing bacteria), high seed production, and lack of seed dormancy. These characters are common of many early successional woody plants that dominate newly exposed surfaces along rivers (Sigafoos 1964, Hupp 1992, Karrenberg et al. 2002). Alnus acuminata does not resprout from roots. It is a deciduous species which forms distinct annual tree rings, and its longevity rarely exceeds 100 years (Sidan \& Grau 1998).

\section{Study area}

The study was conducted in Tucumán Province, north west Argentina (Fig. 1). Regional precipitation is orographic and occurs when wet fronts coming from the southeast collide with the sub-Andean mountain ranges. Precipitation has a highly seasonal, monsoonal regime, with more than $80 \%$ falling between late spring and early autumn (November-April) (Bianchi \& Yáñez 1992). Summer rainfall occurs as heavy local or frontal storms, while winter rainfall is weak and persistent. In contrast to rivers in warm-dry regions (e.g., Baker 1990, Stromberg et al 1991, Scott et al. 1997), the terraces of upland rivers in north west Argentina seem to maintain sufficient moisture for the establishment of tree saplings throughout the years.

The rivers considered in this study are mountain boulder and cobble-bed braided rivers that descend from the eastern slopes of the Cumbres Calchaquíes and Nevados del Aconquija mountain ranges $(>4,000 \mathrm{~m}$ ) and drain into the main Salí-Dulce river system. River-flow comes mostly from direct rainfall; snowmelt contribution is minor.

Mountain riparian forests in the study area are largely dominated by A. acuminata. In some locations Salix humboldtiana may also be abundant. Scattered individuals of Juglans australis, Allophylus edulis and Sambucus peruviana occur along river edges in apparent association with fine sediments and nutrientrich soils (Aceñolaza 1996).

\section{Sampling}

Between spring 1996 and 1997, the establishment patterns within three riparian forest plots were reconstructed by means of tree age estimation and mapping. We selected sample sites that included large trees and covered as much variation in tree size as could be found in order to test the hypothesis that trees were arranged in distinct cohorts.

Every living A. acuminata tree $(>0.3 \mathrm{~m}$ height) was mapped and cored or crosssectioned in one $1,120 \mathrm{~m}^{2}$ plot by La Horqueta river $\left(27^{\circ} 8^{\prime} \mathrm{S}, 65^{\circ} 48^{\prime} \mathrm{W}, 1,210 \mathrm{~m}\right.$ of altitude) and two neighbouring $780 \mathrm{~m}^{2}$ plots by Potrero river $\left(26^{\circ} 28^{\prime} \mathrm{S}, 65^{\circ} 37^{\prime} \mathrm{W}, \sim 1,800 \mathrm{~m}\right.$ of altitude) that were roughly $500 \mathrm{~m}$ away from each other (Fig. 1). Small trees $(<3.5 \mathrm{~cm} \mathrm{DBH})$ were cross-sectioned, large trees were cored once with increment borers, and very large individuals (> $20 \mathrm{~cm} \mathrm{DBH}$ ) were cored twice in order to obtain more reliable estimates of tree ages. All samples were taken between 15-25 $\mathrm{cm}$ above soil surface to include the first year of growth following germination (we estimated the average height of a 1-year-old sapling to be $60 \mathrm{~cm}$, by dating cross sections at different heights for seven saplings). We also surveyed Potrero river for large trees with floodscars and took nine wedges using a chainsaw.

Tree cores, cross sections, and wedges were processed following standard dendrochronological procedures (Stokes \& Smiley 1968). When increment borer samples did not reach the centre, tree age was estimated following geometrical procedures based on the curvature and width of the innermost rings (Duncan 1989). We dated flood scars by counting annual rings backwards from the outermost ring, which corresponds to the sampling date because wedges were taken from living trees. We did not cross-date flood scars nor cores but we verified ring counts at least once for all samples and, in the cases where we had two cores for the same individual with different age estimates (i.e., some trees $>20 \mathrm{~cm}$ $\mathrm{DBH}$ ), we relied on the estimate of cores that reached the center and/or had less compressed rings. We used growth years (August-May) for age estimation instead of calendar years for ease of comparison with hydrological years (July-June). 


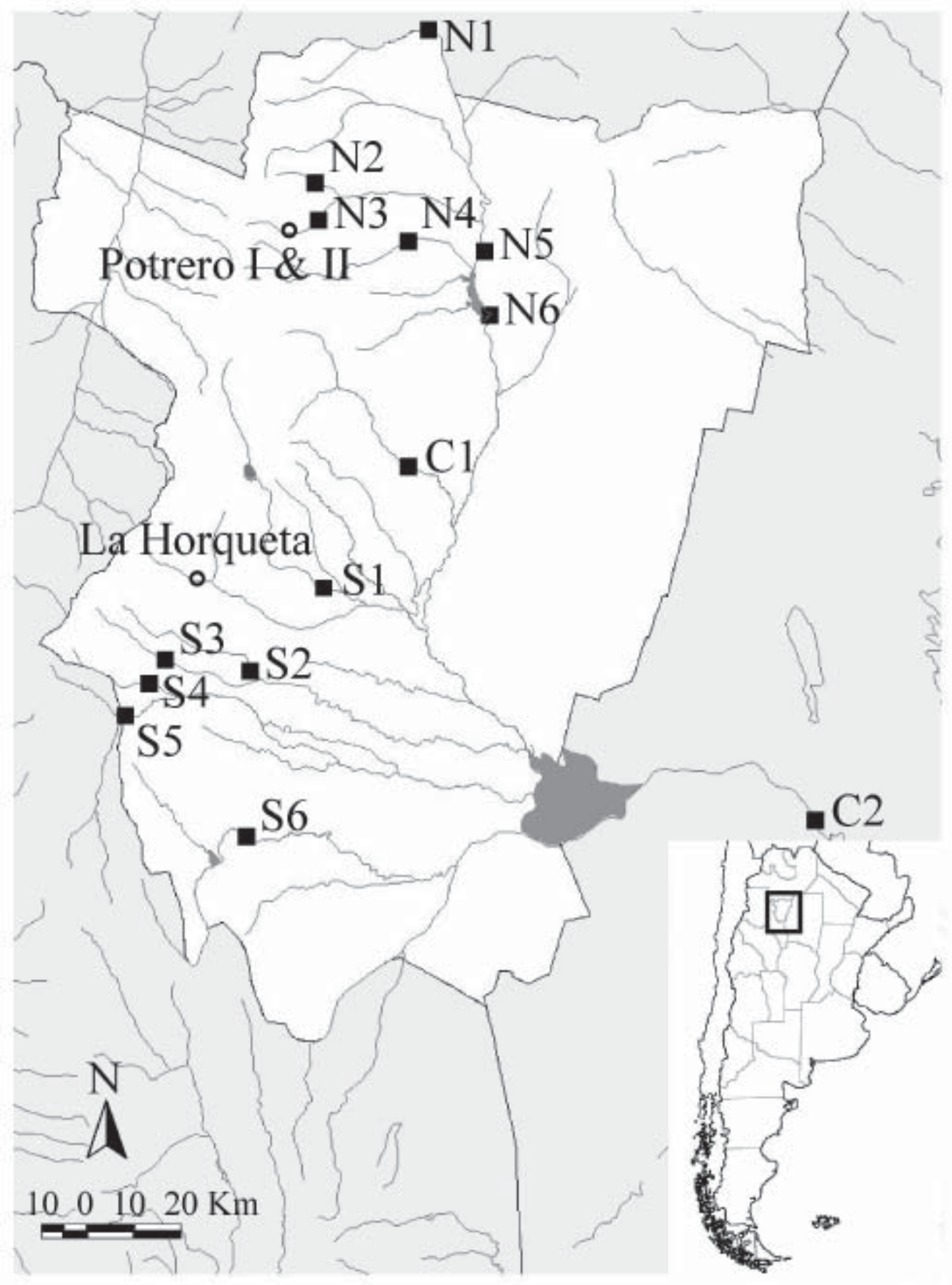

Fig. 1: Location of A. acuminata riparian forest plots (open circles) in Tucumán Province, Argentina. Squares indicate gauge stations used to estimate north $(\mathrm{N})$ and South $(\mathrm{S})$ averages of annual maximum of daily streamflow. Rivers included in the regional averages are: N1 Tala, N2 Rearte, N3 Potrero, N4 Vipos, N5 Salí at San Vicente, N6 Salí at El Cadillal, S1 Los Sosa, S2 Solco, S3 Membrillo, S4 Cochuna, S5 Cañas at Potrero del Clavillo, S6 Marapa, C1Y Lules, and C2 Dulce.

Ubicación de parcelas de bosque ripario de A. acuminata (círculos abiertos) en la Provincia de Tucumán, Argentina. Los cuadrados señalan estaciones de aforo utilizadas para estimar los promedios norte $(\mathrm{N})$ y sur $(\mathrm{S})$ de registros máximos anuales de caudales medios diarios. Los ríos incluidos en los promedios regionales son: N1 Tala, N2 Rearte, N3 Potrero, N4 Vipos, N5 Salí en San Vicente, N6 Salí en El Cadillal, S1 Los Sosa, S2 Solco, S3 Membrillo, S4 Cochuna, S5 Cañas en Potrero del Clavillo, S6 Marapa, C1Y Lules, y C2 Dulce. 


\section{Data analysis}

To test for the existence of even-aged tree patches and to describe the spatial scale of patchiness, we computed Moran's I spatial autocorrelation index (Duncan \& Stewart 1991). The index estimates how similar in age are trees separated by a given distance class compared with a random spatial distribution of tree ages, with positive and negative values indicating positive and negative spatial autocorrelation, respectively.

Normalised Moran's I Index (Z I (d)) was computed with the program Spatial (Duncan 1995). Trees were considered age-correlated at a given distance class when Z I (d) exceeded the 0.025 significance level ( 2 tailed test). We tested the global significance of I using a Bonferroni correction for multiple tests, with $\alpha=0.025 / 20$ (20 distance classes).

To asses the relationship between stand age structure and flood occurrence, we compared cohort initiation dates with flood scars and river discharge records. For this comparison we referred to records of the maximum daily streamflow in each hydrological year, the best available indicator of summers with large floods. Given that local streamflow records are incomplete for the last century (Agua y Energía Eléctrica 1980), we first standardized the gauge records for each river (standardized record = (observed record - mean) / standard deviation), and then computed: (a) a regional mean with standardized records from gauging stations located in the vicinity of Potrero river, (b) and a regional mean with standardized records from gauging stations located in the vicinity of $\mathrm{La}$ Horqueta river (Fig. 1). For simplicity, these variables will be respectively referred as north/ south maximum streamflow. Records from more distant gauge stations in the Lules and Dulce rivers (Fig. 1) were included in both regional averages for the period 1914-1915 to 1934-1935 because these are the only records available in this period together with the Salí River from 1913-1914 to 1925-1926. No dams were located upstream of the sampled forest stands, but some were located upstream of gauge stations. This should not affect the regional maximum streamflow estimates because the standardized local records measure relative inter-annual rather than absolute streamflow.
To test for an association between cohort initiation dates and regional maximum streamflow we used a randomization test. We compared the sum of intervals (in years) linking observed cohort initiation dates and their nearest regional riverflow peak (larger than one standard deviation) against the sum of intervals computed for randomly generated cohort initiation dates. Intervals were measured in either direction to allow for potential errors in age estimation which could cause initiation dates to preceed peaks in riverflow.

To test for an association between maximum streamflow and ENSO, we computed Spearman correlations between North/South maximum streamflow, and sea surface temperature (SST) anomalies in the Niño3 region $\left(5^{\circ} \mathrm{N}-5^{\circ} \mathrm{S}\right.$ and $150^{\circ}-90^{\circ} \mathrm{W}$ ) (Trenberth 1997). The ENSO index was computed both as: (a) May $_{t}-$ April $_{t+1}$ means of el Niño3 SST anomalies to make them coincide with the approximate onset of El Niño events, and (b) as November $_{\mathrm{t}}$-March $_{\mathrm{t}+1}$ seasonal averages which coincide with peaks in El Niño development and most rainfall in north west Argentina. We also tested for cross-correlations because there are indications of a possible lag between El Niño and heavy rains in north west Argentina (Bianchi \& Yáñez 1992). Since the SST records are incomplete before 1950, we used data reconstructed by reduced space optimal analysis (Kaplan et al. 1997), available at the LDEO/IRI Data Library website.

\section{RESULTS}

Distinct cohorts of trees provide evidence of past disturbances. At La Horqueta River we identified one cohort of four trees established between growth years 1919-1920 and 19241925, one individual established in 1945-1946, and a second cohort established between 19721973 and 1979-1980 (Fig. 2D).

A different pattern of recruitment was found at Potrero river. Potrero plot $\mathrm{I}$ is composed of three cohorts established between 1935-1936 and 1940-1941, 19561957 and 1961-1962, and 1984-1985 and 1992-1993 (Fig. 2A). Except for a pair of trees established in 1949-1950 and 1955-1956, a similar, consistent, establishment pattern was found at Potrero plot II (Fig. 2B). 


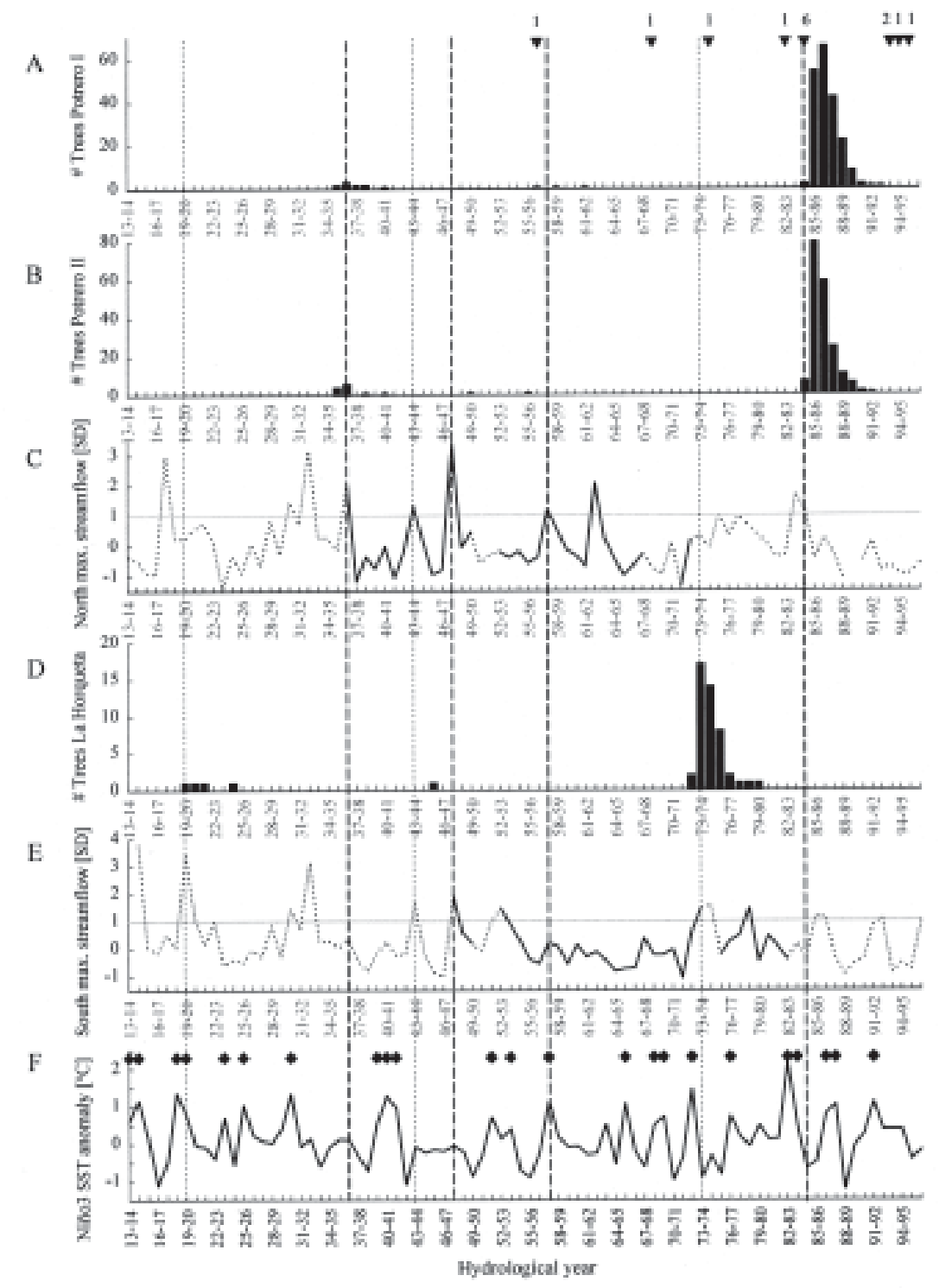

Fig. 2: Histrograms represent A. acuminata tree age structure at: (A) Potrero river Plot I (211 trees), (B) Potrero river Plot II (204 trees), and (D) La Horqueta River Plot (51 trees). Line plots indicate records of standardized annual maximum of daily streamflow averaged for rivers near to: (C) Potrero river at the north of Tucumán Province, and (E) La Horqueta river at the south of Tucumán Province. Solid lines in (C) and (E) correspond to years with streamflow records of three or more gauge stations and dotted lines to years with one or two records. (F) May $\mathrm{t}_{\mathrm{t}}$ April $_{\mathrm{t}+1}$ sea surface temperatures anomalies averaged for the Niño3 region $\left(5^{\circ} \mathrm{N}-5^{\circ} \mathrm{S}\right.$ and $\left.150^{\circ}-90^{\circ} \mathrm{W}\right)$; $\nabla$ number of flood scar dates reconstructed from nine tree wedges sampled along Potrero river; El Niño years defined as in Trenberth (1997). Vertical dashed and dotted lines indicate possible standoriginating flood years for Potrero and La Horqueta River respectively.

Los histogramas representan la estructura de edades de A. acuminata en las parcelas: (A) río Potrero I (211 árboles), (B) río Potrero II (204 árboles), y (D) río La Horqueta (51 árboles). Los gráficos de líneas muestran registros máximos anuales de caulades medios diarios. Dichos registros estan estandarizados y promediados para: (C) ríos cercanos al río Potrero en el norte de la provincia de Tucumán, y (E) ríos cercanos al río La Horqueta en el sur de provincia de Tucumán. Las líneas sólidas en (C) y (E) representan años con registros de tres o más estaciones de aforo y las líneas punteadas años con uno o dos registros. (F) Anomalías de temperaturas superficiales de mar promediadas entre mayo ${ }_{t}$-abril $1_{t+1}$ para la región Niño3 $\left(5^{\circ} \mathrm{N}-5^{\circ} \mathrm{S}\right.$ y $\left.150^{\circ}-90^{\circ} \mathrm{O}\right) ; \boldsymbol{\nabla}$ número de cicatrices reconstruidas de cuñas tomadas en nueve árboles en el río Potrero; $\bullet$ Años de El Niño según Trenberth (1997). Las líneas verticales a rayas y puntos indican posibles años de crecientes para el río Potrero y La Horqueta respectivamente. 
Younger cohorts, the best represented in terms of number of individuals and with more precise age estimations, showed a skewed reverse $\mathrm{J}$-shaped tree age structure in the three plots (Fig. 2A, 2B, 2D). Tree age range of a single cohort spanned up to 8 years, with $80 \%$ or more of the stems within a 3-year interval.

The sampled plots had a closed canopy and no saplings were found in any of the plots, which reflects the light-demanding nature of this tree species. Alnus acuminata was the only tree species at both Potrero river plots. At $\mathrm{La}$ Horqueta river plot, small stems $(<5 \mathrm{~cm} \mathrm{DBH})$ of five other tree species were mixed with $A$. acuminata (nine individuals of Allophylus edulis, one Cedrela lilloi, one Juglans australis, one Parapiptadenia excelsa and one Xylosma pubescens), comprising $20 \%$ of all stems.

Tree distribution maps show that distinct tree cohorts are spatially clumped, which provides further evidence of their relationship with past disturbances (Fig. 3). Spatial autocorrelation analysis of the La Horqueta plot and Potrero plot I (Fig. 4) show spatial grouping of similar-aged trees. Both correlograms have overall significance under a Bonferroni correction (Potrero I, P $=0.0008, \alpha /$ $\mathrm{K}=0.0013 ;$ La Horqueta, $\mathrm{P}=0.00009, \alpha / \mathrm{k}=$ 0.0012 ), providing statistical evidence for the presence of spatially discrete even-aged tree patches. Positive autocorrelation at short distances for both plots probably results from young tree clustering, as seen in the tree distribution maps (Fig. 3). Positive autocorrelation at larger distance classes (13.5$14.25 \mathrm{~m}$ ) in the Potrero plot I, could be a result of spatial segregation of young trees in two parallel bands. Positive autocorrelation at large distance classes in the La Horqueta plot is due to spacing between old trees. We verified this by artificially shifting the position of old trees in the center of the plot and re-running Moran's I. Though the Potrero plot II was not mapped, personal observations indicate that larger trees, which correspond to the older tree cohorts (> 41 years old), were clearly clumped on one side of the plot and spatially segregated from the younger cohort.
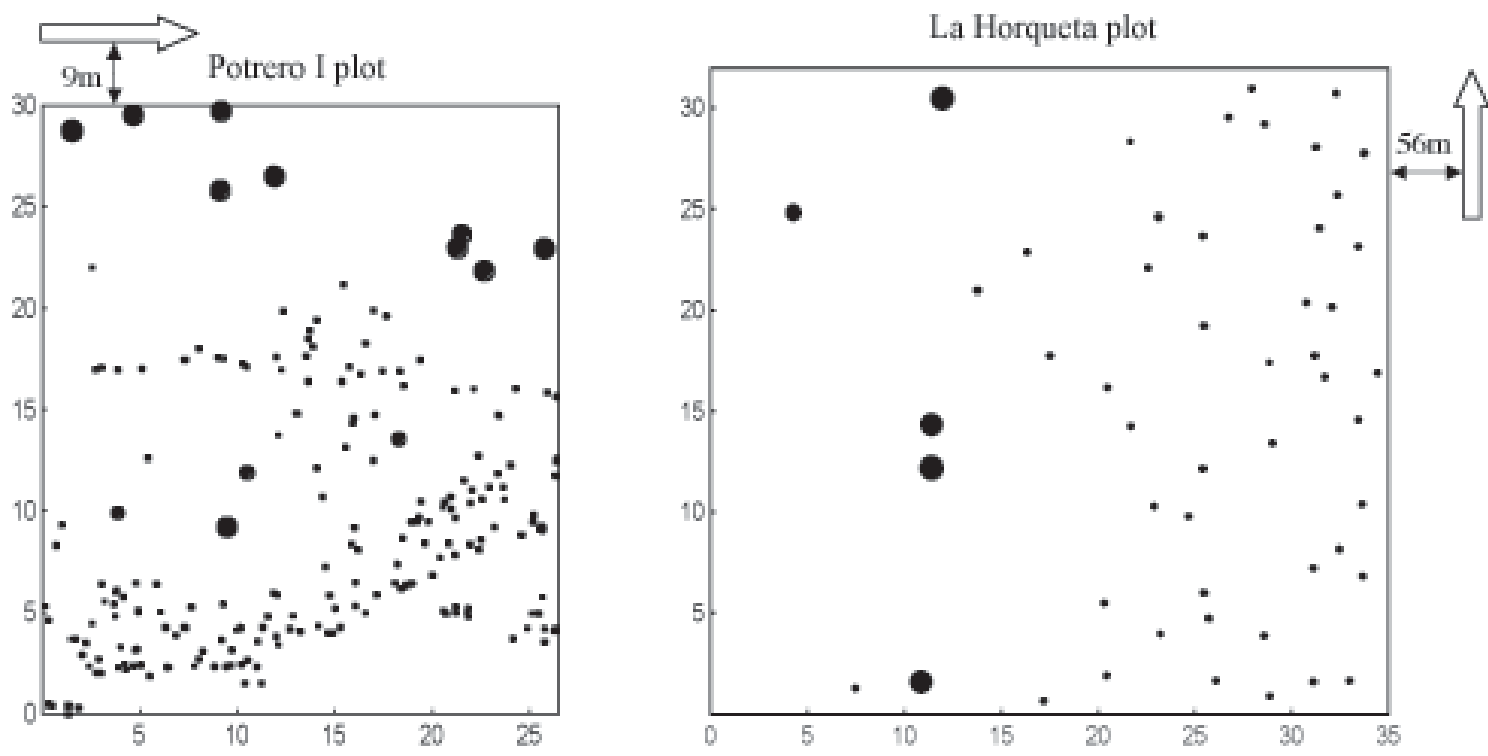

Fig. 3: Spatio-temporal distribution of trees at La Horqueta and Potrero river plot I. Circle size increases in proportion to tree age and plot size scale is in meters. Arrows indicate the approximate direction of river flow and their distance from the edge of the plots.

Distribución espacio-temporal de árboles en las parcelas de La Horqueta y río Potrero I. El tamaño de los círculos aumenta en proporción a la edad de los árboles y el tamaño de las parcelas está expresado en metros. Las flechas indican dirección y sentido aproximado de flujo de los ríos y su distancia respecto al margen de las parcelas. 

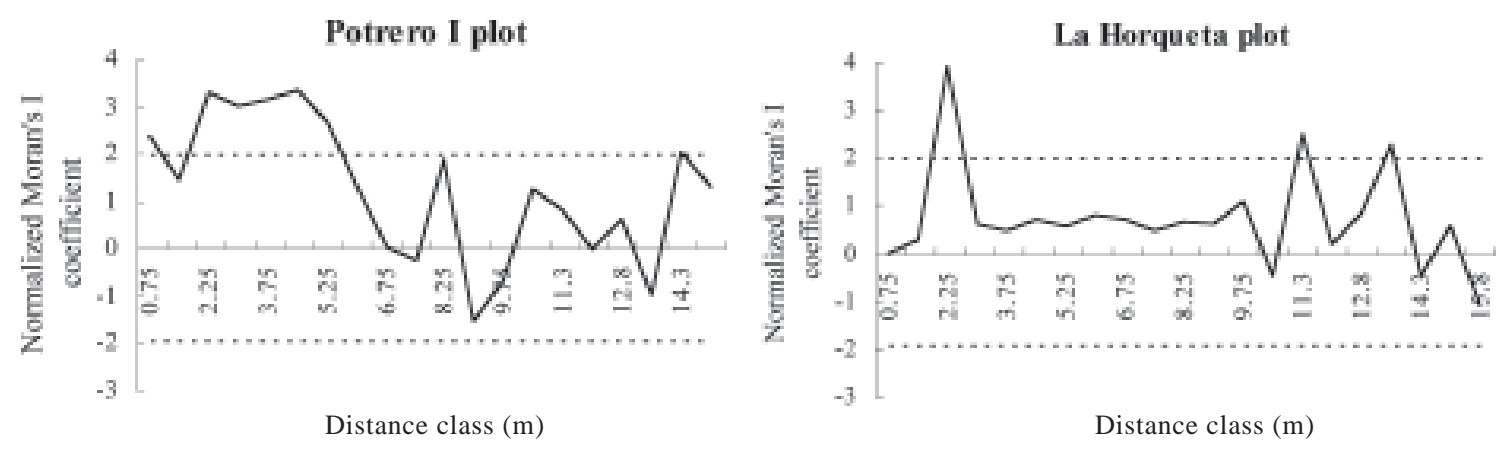

Fig. 4: Spatial correlogram of Alnus acuminata tree ages. Dashed lines indicate the 0.025 significance level.

Correlograma espacial para las edades de Alnus acuminata. Las líneas a rayas indican el nivel de significancia de 0,025.

Establishment peaks at both Potrero river plots occurred one to three years after the major flood recorded in 1984-1985, as evidenced by six flood scars (Fig. 2A, 2B). Events recorded by only one scar, especially younger ones, may only represent minor events rather than large flood events.

Three cohort initiation dates and two isolated trees established within an interval between the same year and two years after a register larger than one standard deviation in the regional maximum streamflow record (vertical lines in Fig. 2). However, two other cohort initiation dates identified in the Potrero river plots (1935-1936 and 1956-1957) anticipate by one year the peaks in regional maximum streamflow. We evaluated the statistical significance of these associations with randomisation tests. For Potrero river, four cohort initiation dates (derived from the two stands) were randomly generated on each iteration process. These dates were confined within the start of the hydrologic register and the plot sampling date (1913-1914 to 19961997). For La Horqueta River, three cohort initiation dates within 1914-1915 and 19961997 were generated on each iteration. For Potrero river we found that 26 out of 250 iterations displayed total intervals that were equal or lower than the observed five years gap $(\mathrm{P}=0.104)$, and for La Horqueta river 17 out of 250 randomizations displayed total time-spans that were equal or lower than the observed two years gap $(P=0.068)$. Therefore, the possibility that the observed patterns were random was relatively small, giving some support to the correlation between tree cohort initiation dates and regional maximum streamflow records.

To analyze the relationship between standoriginating floods and El Niño events we assumed that a register in regional maximum streamflow larger than one standard deviation closer to the oldest tree in each cohort (or isolated tree) indicated a stand-initiation flood. By combining the data from both rivers (vertical lines in Fig. 2), we found that: (a) two of seven stand initiation floods (1919-1920 La Horqueta River, and 1957-1958 Potrero river) coincided with el Niño events (diamonds in Fig. 2), (b) two others showed a one-year lag from El Niño events (1973-1974 La Horqueta River and 1984-1985 Potrero River), and (c) the three remaining floods (1935-1936, 19431944, and 1947-1948), two of them recorded from single trees, were clearly not related to El Niño. If, on the other hand, instead of looking at the cohort initiation floods, we test for an association between the complete records of regional maximum streamflow and el Niño3 SST anomaly index, we find no correlation (Table1, Fig. 2C, 2E, 2F).

\section{DISCUSSION}

The results provide evidence of the influence of mountain river floods in structuring $A$. acuminata riparian forests. Coetaneous patches of $A$. acuminata arise from massive regeneration following catastrophic river floods that eliminate previous vegetation and originate bare fluvial 
surfaces suitable for establishment of this pioneer tree species. This reiterates observations of several other studies which state the importance of floods as natural disturbances that affect mortality and recruitment of riparian trees, thus producing strong modifications in landforms and vegetation across the riparian landscape in brief periods of time (Hack \& Goodlet 1960, Friedman et al. 1996, Scott et al. 1997, Karrenberg 2002).

\section{Spatio-temporal forest structure}

The reverse-J shape of the age histogram (Fig. $2 \mathrm{~A}, 2 \mathrm{~B}, 2 \mathrm{D})$ of the youngest tree cohorts indicates the presence of a continuous massive seed source over past years and of appropriate conditions for establishment during stand initiation: stems invading early would grow rapidly, occupy the growing space and exclude later arriving trees (Oliver \& Larson 1996). Though the observed age range of single cohorts span up to 8 years and though this range may be underestimated because of overlooking dead trees which could have originated later in stand initiation, it is clear that most trees became established during the first three years after formation of a bare fluvial plain. This narrow age range is comparable to that observed for riparian cottonwood (Populus sp.) forests in North America, which also establish even-aged stands mainly up to the third year after creation of bare alluvial deposits (Bradley \& Smith 1986, Baker 1990, Stromberg et al. 1991). In neighbouring $A$. acuminata forest-grassland ecotones of north west Argentina, the occurrence of fire and grazing at intermediate frequencies, can reduce competition between juvenile trees and non-forest vegetation and favor forest expansion (Grau 1985, Grau \& Veblen 2000). The evidence available indicates that $A$. acuminata stand formation in mountain slopes takes place mainly within a three to four year period following a fire (Grau \& Veblen 2000).

It is likely that the age range of single patches may compress during stand development due to mortality of the youngest trees (Oliver \& Larson 1996). The six-year age span observed for old cohorts could be attributed to errors in tree age estimation because old trees tend to have groups of compressed rings, which make age estimation uncertain in some cases. The reduced number of old trees in relation to young trees can be attributed to intraspecific competition, which seems to be an important cause of mortality in young dense stands and, at a larger scale, to the erasing effect of subsequent floods.

TABLE 1

Results of rank correlation analysis between mean sea surface temperature anomalies in El Niño3 region $\left(5^{\circ} \mathrm{N}-5^{\circ} \mathrm{S}\right.$ and $\left.150^{\circ}-90^{\circ} \mathrm{W}\right)$ and regional maximum streamflow in Tucumán Province,

Argentina. Regional maximum streamflow are standardized records of annual maximum streamflow which were averaged for rivers in the vicinity of Potrero (north maximum streamflow) and La

Horqueta river (south maximum streamflow). See Fig. 1 for location of gauging stations. $t$ to $t+1$ : same hydrological year, t-1 to t: previous hydrological year

Resultados de análisis de correlación no paramétricos entre anomalías de temperatura superficial de mar en la región El Niño $3\left(5^{\circ} \mathrm{N}-5^{\circ} \mathrm{S}\right.$ y $\left.150^{\circ}-90^{\circ} \mathrm{O}\right)$ y promedios regionales de caudales máximos para la provincia de Tucumán, Argentina. Los promedios regionales de caudales máximos son registros de valores máximos anuales en caulades medios diarios que fueron estandarizados para cada río antes de computar promedios con los registros de estaciones de aforo próximas al río Potrero (north maximum streamflow) y al río La Horqueta (south maximum streamflow). La Fig.1 indica la ubicación de las estaciones de aforo. $\mathrm{t}$ a $\mathrm{t}+1$ : año hidrológico vigente, $\mathrm{t}-1$ a t: año hidrológico previo

\begin{tabular}{|c|c|c|c|c|c|c|}
\hline & \multicolumn{3}{|c|}{ North maximum streamflow } & \multicolumn{3}{|c|}{ South maximum streamflow } \\
\hline & $\mathrm{n}$ & Spearman's R & $\mathrm{P}$-value & $\mathrm{n}$ & Spearman's R & P-value \\
\hline Niño3 $\operatorname{Nov}_{t}-\operatorname{Mar}_{t+1}$ & 83 & -0.05 & 0.655 & 83 & 0.093 & 0.402 \\
\hline Niño3 $\mathrm{May}_{\mathrm{t}}-\mathrm{Apr}_{\mathrm{t}+1}$ & 83 & 0.011 & 0.92 & 83 & 0.144 & 0.193 \\
\hline Niño3 $\operatorname{Nov}_{t-1}-$ Mar $_{t}$ & 82 & 0.026 & 0.815 & 83 & 0.118 & 0.287 \\
\hline Niño3 $\mathrm{May}_{\mathrm{t}-1}-\mathrm{Apr}_{\mathrm{t}}$ & 82 & 0.022 & 0.848 & 83 & 0.091 & 0.415 \\
\hline
\end{tabular}


Riparian forests, floods, and ENSO

In addition to forest temporal and spatial structure, links between tree age structure and streamflow registers also provide evidence that $A$. acuminata stands are created after large floods. The anomalous observation that two cohort initiation dates (1935-1936 and 1956-1957) precede by one year a peak in regional maximum streamflow (larger than one standard deviation) that presumably originated the cohort, can be attributed to two possible causes. Errors in tree age estimation due to compressed rings in old trees, or double annual rings which derive from floodscars (see Grau et al. 2003), are critical if we consider that most old cohort initiation dates are based on one or a small number of trees. Because the correlation between maximum streamflow records of individual rivers is not strong (results not shown), it is also important to consider that actual stand-originating floods in a particular river could be hidden in the regional average of maximum streamflow records. Despite the imprecision of exact flood and cohort initiation dates, it is striking that the randomization test gave partial evidence of an association between regional maximum streamflow larger than one standard deviation and cohort initiation dates.

The flood-establishment pattern is best shown by the largest and youngest tree cohorts in both rivers. In Potrero river, the stand initiation dates, flood scars, and river gauge records show that massive recruitment started in the growing season following the catastrophic flood. This one-year lag for recruitment could result from late summer or recurrent floods combined with the rapid decrease of $A$. acuminata seed viability (Grau 1985) after the June-August seed-rain. The youngest cohort in La Horqueta, instead, was initiated in the same growing season of a large register in regional maximum streamflow (more than one standard deviation). However, we lack floodscar records for this river that would allow us to corroborate the synchronization between massive establishment and a presumably early growing season flood. A striking observation is the other large flow that followed the stand initiation date at La Horqueta river (1974-75). If it occurred at La Horqueta, this flood didn't affect the sampled stand, but it may well have occurred only in neighboring rivers included in our regional record of maximum streamflow.
Consistent age structure between the two plots sampled in Potrero river support our perception that the recorded cohorts are representative of the tree age structure in each watershed. Although the plots sampled represent a small fraction of forest cover in each valley, our observations indicate that riparian forests along the margins of both rivers consist mainly of trees of similar size (possible similar age) as that of the younger sampled cohorts (i.e., stands initiated after the 1984-1985 flood within Potrero river and after the 1973-1974 flood within La Horqueta river). Flood years and resulting riparian $A$. acuminata stands seem to occur at different times between Potrero and La Horqueta rivers. This might be generalized to differences between North and South regions in Tucumán Province as implied by differences in maximum discharge records between north and south (Fig. 2C, 2E). The different patterns observed between rivers lessen support for the hypothesis that large-scale processes such as ENSO control peak discharges and floods in north west Argentinean mountain rivers.

The positive influence of El Niño events on mean annual precipitation in north west Argentina (Trauth et al. 2000), holds for mean annual streamflow in Tucumán Province (results not shown) but does not apply for maximum streamflow in this area. This is not surprising considering the stochastic nature of extreme events. However, the fact that two of seven probable stand-originating floods coincide with El Niño, and two others occur on years following El Niño events, allows the possibility of a more complex connection with ENSO where floods occur either on the same or following summer of an El Niño event. An unpublished study quoted by Bianchi \& Yañez (1992) detected a one-year lag between copious rains in Salta Province (north of Tucumán) and some El Niño events. They suggested that increased water accumulation in the Pantanal region during El Niño years would overfill continental air masses the following year and result in intense precipitation over the Andes. A similar explanation would be that increased soil water logging during El Niño in the Andean foothills of NW Argentina could facilitate runoff and floods during the following hydrological year. The influence of other large circulation patterns and their interaction with ENSO should also be considered. Such is the 
case for the South Atlantic Convergence Zone or the South American Low Level Jet whose influence on precipitation patterns in NW Argentina is increasingly recognized.

To conclude, our results do not support a strong, direct, association between stand originating floods and El Niño events. Studies of floods and low flows in New Zealand rivers (Mosley 2000) and droughts in Malaysia (Walsh 1996) have also failed to detect a clear association with ENSO. This indicates that the effect of ENSO on the dynamics of continental biotic communities may be variable and needs to be interpreted with caution.

Rivers are sensitive to climatic (hydrological) fluctuations because they concentrate the precipitation occurring over large areas (the catchment) into a constricted drainage belt. This seems particularly important in mountain river catchments because of steep relief and intense storm activity. The next research challenge is to increase the sampling effort to date A. acuminata riparian forests at landscape and regional scales, in order to assess the impact and synchronism of climate and disturbance regimes among catchments (e.g., to asses the relative importance of local vs. large frontal storms), and to extend research in order to identify the major drivers of severe river floods.

\section{ACKNOWLEDGMENTS}

This research work was inspired by Alejandro D. Brown. We are very grateful to Héctor Ricardo Grau and Juan Manuel Morales for advice throughout the research, and to Marcos Easdale for fieldwork assistance. We also thank Jeremy Lichstein, John Healey, and the referees for valuable comments on the manuscript, and Néstor Ignacio Gasparri for assistance with Fig 1. Tomás A. Easdale was supported by a Consejo Nacional de Investigaciones Científicas y Técnicas (CONICET) graduate scholarship.

\section{LITERATURE CITED}

ACEÑOLAZA PG (1996) Estructura y dinámica de bosques de Aliso (Alnus acuminata H.B.K. ssp. acuminata) de la provincia de Tucumán. Ph.D. Thesis, Universidad Nacional de Tucumán, San Miguel de Tucumán, Argentina. 280 pp.
AGUA Y ENERGÍA ELÉCTRICA (1980) Estadística hidrológica hasta 1980. Fluviometría. Tomo I. Ministerio de Obras y Servicios Públicos, Subsecretaría de Energía Hidroeléctrica y Térmica, Buenos Aires, Argentina. $420 \mathrm{pp}$.

BAKER WL (1990) Climatic and hydrologic effects on the regeneration of Populus angustifolia James along the Animas River, Colorado. Journal of Biogeography 17: 59-73.

BELL DA (1991) Distribución del bosque de Aliso del cerro, Alnus acuminata (Betulaceae) en la Provincia de Tucumán, Argentina. Boletín de la Sociedad Argentina de Botánica (Argentina) 27: 21-30.

BIANCHI AR \& CE YÁÑEZ (1992) Las precipitaciones del noroeste argentino. Instituto Nacional de Tecnología Agropecuaria (INTA), Buenos Aires, Argentina. 383 pp.

BRADLEY CE \& DG SMITH (1986) Plains cottonwood recruitment and survival on a prairie meandering river floodplain, Milk river, southern Alberta and northern Montana. Canadian Journal of Botany 64: 1433-1442.

CABRERA AL (1976) Regiones fitogeográficas argentinas. Enciclopedia Argentina de Agricultura y Ganadería 2. Acme, Buenos Aires, Argentina. 85 pp.

CAMILLONI IA \& VR BARROS (2003) Extreme discharge events in the Parana river and their climate forcing. Journal of Hydrology (The Netherlands) 278: 94-106.

CLARK JS (1988) Effect of climate change on fire regimes in northwestern Minnesota. Nature 334: 233-235.

DUNCAN RP (1989) An evaluation of errors in tree age estimates based on increment cores in kahikatea (Dacrycarpus dacrydioides). New Zealand Natural Sciences 16: 31-37.

DUNCAN RP (1995) Spatial analysis programs. Lincoln University, Canterbury, New Zealand. 8 pp.

DUNCAN RP \& GH STEWART (1991) The temporal and spatial analysis of tree age distributions. Canadian Journal of Forest Research 21: 1703-1710.

EVERITT BL (1968) Use of cottonwood in an investigation of the recent history of a flood plain. American Journal of Science 266: 417-439.

FOSTER DR (1988) Species and stand response to catastrophic wind in central New England, U.S.A. Journal of Ecology 76: 135-151.

FRIEDMAN JM, WR OSTERKAMP \& W LEWIS (1996) Channel narrowing and vegetation development following a great plains flood. Ecology 77: 2167-2181.

GRAU A (1985) La expansión del aliso del cerro (Alnus acuminata H.B.K. ssp. acuminata) en el noroeste de Argentina. Lilloa (Argentina) 36: 237-247.

GRAU HR \& TT VEBLEN (2000) Rainfall variability, fire and vegetation dynamics in Neotropical montane ecosystems in north-western Argentina. Journal of Biogeography 27: 1107-1121.

GRAU HR, TA EASDALE \& L PAOLINI (2003) Subtropical dendroecology-dating disturbances and forest dynamics in northwestern Argentina montane ecosystems. Forest Ecology and Management (The Netherlands) 177: 131-143.

HACK JT \& JC GOODLET (1960) Geomorphology and forest ecology of a mountain region in the central Appalachians. Professional Paper 347, United States Geological Survey, USA. 66 pp.

HOLMGREN M, M SCHEFFER, E EZCURRA, JR GUTIÉRREZ \& GMJ MOHREN (2001) El Niño effects on the dynamics of terrestrial ecosystems. Trends in Ecology and Evolution 16: 89-94. 
HUECK K (1978) Los bosques de Sudamérica. Sociedad Alemana de Cooperación Técnica (GTZ) Ltda., Berlin, Germany. 476 pp.

HUPP CR (1992) Riparian vegetation recovery patterns following stream channelization: a geomorphic perspective. Ecology 73: 1209-1226.

JAKSIC FM (2001) Ecological effects of El Niño in terrestrial ecosystems of western South America. Ecography 24: 241-250.

KAPLAN A, Y KUSHNIR, MA CANE \& MB BLUMENTHAL (1997) Reduced space optimal analysis for historical data sets: 136 years of Atlantic sea surface temperatures. Journal of Geophysical Research 102: 27835-27860.

KARRENBERG S, PJ EDWARDS \& J KOLLMANN (2002) The life history of Salicaceae living in the active zone of floodplains. Freshwater Biology 47: 733-748.

MOSLEY MP (2000) Regional differences in the effects of El Niño and La Niña on low flows and floods. Hydrological Sciences Journal (United Kindom) 45: 249-267.

OLIVER CD \& BC LARSON (1996) Forest stand dynamics. Wiley, New York, New York, USA. xviii $+520 \mathrm{pp}$.

OVERPECK JT, D RIND \& R GOLDBERG (1990) Climate-induced changes in forest disturbance and vegetation. Nature 343: 51-53

PICKETT STA \& PS WHITE (eds) (1984) The ecology of natural disturbance and patch dynamics. Academic Press, Orlando, Florida, USA. xiv +472 pp.

SCHWEINGRUBER FH (1996) Tree rings and environment dendroecology. Swiss Federal Institute for Forest, Snow and Landscape Research, Haupt, Bern, Switzerland. 609 pp.

SCOTT ML, GT AUBLE \& J FRIEDMAN (1997) Flood dependency of cottonwood establishment along the Missouri River, Montana, USA. Ecological Applications 7: 677-690.

Associate Editor: Christopher Lusk

Received November 22, 2004; accepted May 10, 2005
SIDAN OM \& A GRAU (1998) Dinámica de crecimiento del Aliso del cerro (Alnus acuminata) en áreas de montaña de Tucumán y Catamarca (Argentina). Lilloa (Argentina) 39: 191-200.

SIGAFOOS RS (1964) Botanical evidence of floods and flood-plain deposition. United States Geological Survey, Professional Paper 485A. 35 pp.

SOUSA WP (1984) The role of disturbance in natural communities. Annual Review of Ecology and Systematics 15: 353-391.

STOKES MA \& TL SMILEY (1968) An introduction to tree ring dating. University of Chicago Press, Chicago, Illinois, USA. xiv + 73 pp.

STROMBERG JC, DT PATTEN \& BD RICHTER (1991) Flood flows and dynamics of Sonoran riparian forests. Rivers (USA) 2: 221-235.

SWETNAM TW \& JL BETANCOURT (1990) FireSouthern Oscillation relations in the southwestern United States. Science 249: 1017-1020.

TOWNSEND CR (1989) The patch dynamics concept of stream community ecology. Journal of the North American Benthological Society 8: 36-50.

TRAUTH MH, RA ALONSO, KR HASELTON, RL HERMANNS \& MR STRECKER (2000) Climate change and mass movements in the NW Argentine Andes. Earth and Planetary Science Letters (The Netherlands) 179: 243-256.

TRENBERTH KE (1997) The definition of El Niño. Bulletin of the American Meteorological Society 78: 2771-2777.

WALSH RPD (1996) Drought frequency changes in Sabath and adjacent parts of northern Borneo since the late nineteenth century and possible implications for tropical rain forest dynamics. Journal of Tropical Ecology 12: 385-407.

WARD JV \& JA STANFORD (1995) Ecological connectivity in alluvial river ecosystems and its disruption by flow regulation. Regulated Rivers: Research and Management (United Kindom) 11: 105-119. 